\title{
Thermal comfort index, physiological variables and performance of quails fed with protein reduction
}

\author{
Ladyanne R. Rodrigues ${ }^{1}$, Dermeval A. Furtado ${ }^{1}$, Fernando G. P. Costa ${ }^{2}$, \\ José W. B. do Nascimento ${ }^{1} \&$ Evaldo de A. Cardoso ${ }^{2}$ \\ ${ }^{1}$ Universidade Federal de Campina Grande/Unidade Acadêmica de Engenharia Agrícola. Campina Grande, PB. E-mail: ladyannezootecnia@hotmail.com; \\ dermeval@deag.ufcg.edu.br (Corresponding author); wallace@ufcg.edu.br \\ ${ }^{2}$ Universidade Federal da Paraíba/Centro de Ciências Agrárias. Areia, PB. E-mail: fperazzo@cca.ufpb.br; evaldo@cca.ufpb.br
}

Key words:

thermal comfort zone physiological variables productive indices

\begin{abstract}
A B S T R A C T
The objective of this study was to determine the effects of environment and electrolyte balance on environmental, physiological and productive indices of Japanese quails. For the experiment, 288 quails were distributed in a randomized block design with six treatments and six replicates of eight birds per experimental unit. The treatments consisted of one basal feed with $20.0 \%$ of crude protein (CP) and the others with a reduction of $3.0 \% \mathrm{CP}$ to achieve six electrolyte balance levels $(166.54 ; 153.47 ; 139.63 ; 139.63 ; 117.13$ and 166.49). As to the environment, there was an increase in air temperature and temperature-humidity index at the hottest hours of the day, causing discomfort to the birds, which increased respiratory rate, but with the maintenance of homeothermy. Differences were observed in feed consumption, water consumption, production, weight of eggs and mass of eggs, due to the electrolyte levels in the feed. For feed conversion, both per mass and per dozen of eggs, there was no statistical difference. The electrolyte balance and environmental indices at the hottest hours of the day did not affect quail production.
\end{abstract}

\section{Palavras-chave:}

zona de conforto térmico variáveis fisiológicas índices produtivos

\section{Índice de conforto térmico, variáveis fisiológicas e desempenho de codornas alimentadas com redução proteica}

\begin{abstract}
R E S U M O
Objetivou-se, neste trabalho, determinar o efeito do ambiente e do balanço eletrolítico sobre os índices ambientais, fisiológicos e produtivos de codornas japonesas. Utilizaram-se 288 aves distribuídas no delineamento em blocos casualizados com seis tratamentos e seis repetições de oito aves por unidade experimental. Os tratamentos consistiram em uma ração basal com nível de 20,0\% PB e os demais com redução de 3,0\% PB, para alcançar seis níveis de balanço eletrolítico $(166,54 ; 153,47 ; 139,63 ; 139,63 ; 117,13$ e 166,49). Quanto ao ambiente, verificou-se uma elevação na temperatura do ar e no índice de temperatura e umidade nos horários mais quentes do dia, causando desconforto às aves, que elevaram a frequência respiratória, porém com a manutenção da homeotermia. Foram observadas diferenças no consumo de ração, consumo de água, produção, peso e massa de ovo, em razão dos níveis eletrolíticos da ração. Quanto à conversão alimentar tanto por massa quanto por dúzia de ovos, não foi observada diferença estatística. O balanço eletrolítico e os índices ambientais nos horários mais quentes do dia não interferiram na produção das aves.
\end{abstract}




\section{INTRODUCTION}

Quail farming is a poultry activity in expansion, responsible for the generation of jobs and income at all levels of the production chain, and its main products are eggs and meat, which are source of animal protein with high biological value (Moura et al., 2010). Quail farming stands out for the precocity, high laying rate of the birds and the small size required for the production (Guimarães et al., 2014). In order to maximize yield, production and product quality, quails must be well fed and raised in appropriate, equipped installations, such as in automated air-conditioned facilities, allowing the strains of breeders to externalize their production to the maximum.

Identifying the factors that influence animal life quality, such as the stress imposed by seasonal environmental fluctuations, allows performing adjustments in management practices, which lead to sustainability and economic viability (Costa et al., 2012). Thermal discomfort in laying poultry can cause a series of consequences, which in turn are closely related to the decrease in animal performance. Quails can be raised under heat conditions (Umigi et al., 2012), and the ideal air temperature, i.e., the thermal comfort zone (TCZ), for quails in the laying stage, is between 18 and $22{ }^{\circ} \mathrm{C}$, with relative air humidity between 65 and 70\% (Oliveira, 2007).

TCZ is related to the ideal thermal environment in which the amplitude must be restricted, the animal reaches its maximum potential and its body temperature is maintained with minimum use of thermoregulation mechanisms (Baêta \& Souza, 2010). Under these conditions, the birds find perfect conditions to express their best production characteristics (Nazareno et al., 2009) and the energy expenditure to maintain homeothermy is minimal (Baêta \& Souza, 2010). Rectal temperature, respiratory rate and cloacal temperature are considered as important physiological parameters to characterize comfort or stress condition of animals (Guimarães et al., 2014).

Many indices are used to predict animal discomfort and comfort under certain environmental conditions and to evaluate the adjustment of an environment in relation to an animal-raising activity, among which the temperaturehumidity index (THI), calculated from the combined effects of air temperature and relative humidity (Buffington et al., 1997).

As the knowledge on nutrition evolves, diets start being formulated with minimum costs and maximum economic return. Feeding affects quail-farming costs from its base, the animal breeding industry, until the top of the production chain, i.e., slaughterhouses and freezers (Silva et al., 2012). However, the manipulation of the dietary electrolyte balance has been proposed as a means of improving the performance of poultry fed with low-crude protein diets (Oliveira et al., 2012).

For being one of the most important nutrients in feed formulation, protein directly influences poultry performance. Thus, the electrolyte balance needs to be studied in detail, along with the reduction in feed crude protein, since it is an additional tool in poultry feeds, considering that the electrolyte proportion needs to be evaluated and adjusted, in order to contribute to this important segment of the Brazilian poultry farming. In this sense, the electrolyte balance (EB) of the feed is directly related to the internal acid-base equilibrium of the animals and, since feed protein contents vary (Minafra et al., 2009), the electrolyte balance of the diet needs to be adjusted. Based on the above, this study aimed to determine the effects of environment and electrolyte balance on the environmental, physiological and productive indices of Japanese quails.

\section{Material ANd Methods}

The experiment was carried out at the poultry farming module of the Center of Agricultural Sciences of the Zootechny Department of the Federal University of Paraíba, located in the municipality of Areia-PB, Brazil, in the microregion of 'Brejo Paraibano' (06 57' 48" S; $-35^{\circ} 41^{\prime} 30^{\prime \prime}$ W; $618 \mathrm{~m}$ ). According to Köppen's classification, the climate in the region is As', characterized as hot-humid tropical, with rains from autumn to winter, temperatures between 15 and $29^{\circ} \mathrm{C}$ and mean annual rainfall around $1800 \mathrm{~mm}$.

The experimental period of 84 days was divided into four periods of 21 days, and 288 18-week-old Japanese quails (Coturnix coturnix japonica) were used in the study. The treatments consisted of six diets: (T1) control feed, according to animal requirements (NRC, 2004) and based on corn and soybean bran, supplemented with DL-methionine and choline; from T2 to T6, the basal feed was supplemented with different levels of amino acids, in order to obtain six levels of electrolyte balance $(166.54,153.47,139.63,139.63117 .13$ and 166.49). The experimental diets are shown in Table 1.

Quails were housed in sets of galvanized-wire cages with dimensions of $33 \times 33 \times 14 \mathrm{~cm}$, each one with 5 cages. Trough feeders were used to provide balanced feed, which as manually distributed twice a day, and the drinkers were adapted using PET bottles to provide deionized water, both ad libitum.

Meteorological variables inside the facilities were recorded during the experiment; air temperature (Tair, ${ }^{\circ} \mathrm{C}$ ) and relative air humidity (RH, \%) were measured every $3 \mathrm{~h}$ for $24 \mathrm{~h}$, using HT-500 data loggers (Instrutherm Instrumentos de Medição Ltda, SP). The devices were installed in the center of each facility and, based on the obtained data, the temperaturehumidity index (THI) was calculated through the equation proposed by Bunffington et al. (1997).

The following physiological variables were recorded twice a week, at 8 and $16 \mathrm{~h}$, in two randomly selected birds of each plot: respiratory rate (RR), cloacal temperature (CT) and body surface temperature (BST), according to Richards (1971). RR was obtained through visual evaluation, considering the number of breaths in $20 \mathrm{~s}$ and multiplying it by 3 , thus obtaining the number of respiratory movements per minute. CT was measured using a digital clinical thermometer (Model Incoterm) inserted in the cloaca of the quails for 2 min until temperature stabilization. For BST, a laser-sight infrared thermometer (Model AK 32), with operation temperature ranging from -10 to $50{ }^{\circ} \mathrm{C}$, was used to measure the temperatures of the head, crest, back, wing and feet; then, the mean BST was calculated.

Quail performance was evaluated using the following production indices: feed and water consumption, production, weight of eggs, mass of eggs and feed conversion per mass and per dozen of eggs. During the production stage, the eggs 
Table 1. Percent and nutritional composition of the diets

\begin{tabular}{|c|c|c|c|c|c|c|}
\hline \multirow{2}{*}{ Ingredients } & \multicolumn{6}{|c|}{ Treatments } \\
\hline & T1 & $\mathrm{T} 2$ & T3 & T4 & T5 & T6 \\
\hline Corn & 49.324 & 52.236 & 55.709 & 55.683 & 63.715 & 63.284 \\
\hline Soybean bran $45 \%$ & 39.183 & 36.720 & 33.739 & 33.742 & 25.370 & 25.370 \\
\hline Limestone & 7.0743 & 7.0801 & 7.0871 & 7.0871 & 7.1043 & 7.1043 \\
\hline Soybean oil & 2.6806 & 2.1570 & 1.5052 & 1.4942 & 1.1340 & 0.9650 \\
\hline Dicalcium phosphate & 0.9225 & 0.9339 & 0.9479 & 0.9480 & 0.9925 & 0.9925 \\
\hline Salt & 0.5348 & 0.5345 & 0.5343 & 0.5343 & 0.5342 & 0.5342 \\
\hline Methionine & 0.1100 & 0.1280 & 0.1498 & 0.1499 & 0.2153 & 0.2153 \\
\hline Choline & 0.0700 & 0.0700 & 0.0700 & 0.0700 & 0.0700 & 0.0700 \\
\hline Vitamin & 0.0500 & 0.0500 & 0.0500 & 0.0500 & 0.0500 & 0.0500 \\
\hline Mineral & 0.0500 & 0.0500 & 0.0500 & 0.0500 & 0.0500 & 0.0500 \\
\hline Isoleucine & & 0.0396 & 0.0876 & 0.0876 & 0.2257 & 0.2257 \\
\hline Lysine & & & 0.0690 & 0.0689 & 0.2652 & 0.2652 \\
\hline Valine & & & & 0.0334 & 0.1668 & 0.1668 \\
\hline Threonine & & & & & 0.1064 & 0.1064 \\
\hline L-Arginine & & & & & & 0.2546 \\
\hline Inert & & & & & & 0.2265 \\
\hline K carbonate & & & & & & 0.1187 \\
\hline Total & 100.00 & 100.00 & 100.00 & 100.00 & 100.00 & 100.00 \\
\hline \multicolumn{7}{|l|}{ Calculated composition } \\
\hline Crude protein & 20.000 & 17.000 & 17.000 & 17.000 & 17.000 & 17.000 \\
\hline Calcium & 3.0500 & 3.0500 & 3.0500 & 3.0500 & 3.0500 & 3.0500 \\
\hline Available phosphorus & 0.2800 & 0.2800 & 0.2800 & 0.2800 & 0.2800 & 0.2800 \\
\hline Metabolizable Energy & 2800.0 & 2800.0 & 2800.0 & 2800.0 & 2800.0 & 2800.0 \\
\hline Digestible Arginine & 1.4111 & 1.3428 & 1.2600 & 1.2600 & 1.2600 & 1.2600 \\
\hline Digestible Isoleucine & 0.8700 & 0.8700 & 0.8700 & 0.8700 & 0.8700 & 0.8700 \\
\hline Digestible Lysine & 1.0869 & 1.0300 & 1.0300 & 1.0300 & 1.0300 & 1.0300 \\
\hline Digestible Methionine & 0.4135 & 0.4216 & 0.4315 & 0.4316 & 0.4614 & 0.4614 \\
\hline Digestible Methionine + Cystine & 0.7000 & 0.7000 & 0.7000 & 0.7000 & 0.7000 & 0.7000 \\
\hline Digestible Threonine & 0.7415 & 0.7105 & 0.6728 & 0.6727 & 0.6700 & 0.6700 \\
\hline Digestible Tryptophan & 0.2484 & 0.2364 & 0.2218 & 0.2218 & 0.1800 & 0.1800 \\
\hline Digestible Valine & 0.9196 & 0.8824 & 0.8821 & 0.8700 & 0.8700 & 0.8700 \\
\hline Sodium & 0.2300 & 0.2300 & 0.2300 & 0.2300 & 0.2300 & 0.2300 \\
\hline Chlorine & 0.3630 & 0.3631 & 0.3632 & 0.3632 & 0.3632 & 0.3632 \\
\hline Potassium & 0.6600 & 0.6090 & 0.5550 & 0.5550 & 0.4670 & 0.6600 \\
\hline Electrolyte balance & 166.54 & 153.47 & 139.63 & 139.63 & 117.13 & 166.49 \\
\hline
\end{tabular}

${ }^{1}$ Mineral premix per kg of feed: $\mathrm{Mn}, 60 \mathrm{~g} ; \mathrm{Fe}, 80 \mathrm{~g} ; \mathrm{Zn}, 50 \mathrm{~g} ; \mathrm{Cu}, 10 \mathrm{~g}$; Co, 2 g; I, $1 \mathrm{~g}$; and vehicle q.s., $500 \mathrm{~g}$; ${ }^{2}$ Vitamin premix (Concentration/kg): Vit. A - 15,000,000 UI, Vit. D $-1,500,000$ UI, Vit. E - 15,000 UI, Vit.B, $-2.0 \mathrm{~g}$, Vit.B $-4.0 \mathrm{~g}$, Vit B6 - $3.0 \mathrm{~g}$, Vit. $\mathrm{B}_{12}-0.015 \mathrm{~g}$, Nicotinic acid - $25 \mathrm{~g}$, Pantothenic acid - $10 \mathrm{~g}$, Vit.K $-3.0 \mathrm{~g}$, Folic acid $-1.0 \mathrm{~g}$, Selenium - $250 \mathrm{mg}$, and vehicle q.s. $-1,000$ g. ${ }^{3}$ Ethoxyquin $-10 \mathrm{~g}$, and vehicle q.s. $-1,000 \mathrm{~g}$. ${ }^{4}$ Washed sand

were daily collected at $8 \mathrm{~h}$ and the following parameters were recorded in specific forms: laying frequency, intact eggs, broken eggs, cracked eggs, thin-shelled eggs, shell-less eggs, deformed eggs and any other abnormalities.

For quantitative variables, feed consumption $\left(\mathrm{g} \mathrm{bird}^{-1} \mathrm{~d}^{-1}\right)$ was calculated through the difference of weight between the supplied amount and the leftovers in the feeders, dividing the result by the number of quails in each cage. Likewise, water consumption was calculated by the sum of the supplied water minus the sum of the water discarded during the washing of the drinkers and the water left at the end of the experimental periods, measured using a graduated cylinder. Quail weight gain was determined by the difference between initial and final weight in each experimental period. Feed conversion per mass of egg was calculated through the relationship between feed consumption and mass of eggs produced. Feed conversion per dozen of eggs was obtained through the multiplication of the mean feed consumption by the dozen of eggs produced.

For egg production (egg bird ${ }^{-1} \mathrm{~d}^{-1}$ ), the eggs were collected every day, twice a day, in the morning and in the afternoon, and the mean egg production (EP) was obtained by dividing the total egg production by the number of quails, always correcting according to the mortality. Mean egg weight (g) was calculated by dividing the total weight by the number of eggs. Mass of eggs was calculated through the multiplication of egg production by the mean weight of eggs per plot.

The statistical analysis considered a randomized block design, which consisted of six treatments and six replicates, with eight quails per experimental unit for each period of 21 days and two times (8 and $16 \mathrm{~h}$ ). Data were analyzed using the program SAEG (2005) and the means were compared by Tukey test at 0.05 probability level.

\section{Results AND Discussion}

Air temperature (Tair) in the afternoon was higher than in the morning (Table 2 and Figure 1). In addition, at the hottest hours of the day $(9,12$ and $15 \mathrm{~h}$ ), Tair values were 24.5, 25 and $24.8^{\circ} \mathrm{C}$, respectively, which can be considered as above the TCZ for quails. According to Oliveira (2007),

Table 2. Means of the climatic variables air temperature (Tair), relative humidity $(\mathrm{RH})$ and temperature-humidity index (THI) as a function of the period

\begin{tabular}{cccc}
\hline \multirow{2}{*}{ Period } & \multicolumn{3}{c}{ Variables } \\
\cline { 2 - 4 } Morning & Tair $(\circ \mathbf{C})$ & RH $(\%)$ & THI \\
Afternoon & $24.0 \mathrm{Aa}$ & $80.0 \mathrm{Aa}$ & $73.0 \mathrm{Aa}$ \\
\hline
\end{tabular}

*Means followed by the same letter, uppercase in the column and lowercase in the row, do not differ by Tukey test at 0.05 probability level 


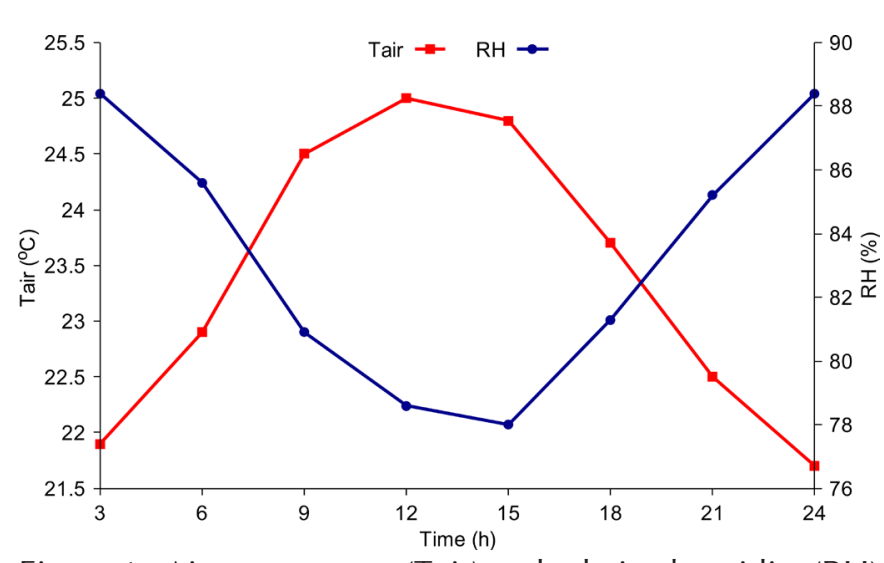

Figure 1. Air temperature (Tair) and relative humidity $(\mathrm{RH})$ inside the facility as a function of time

TCZ should be between 18 and $22{ }^{\circ} \mathrm{C}$, which agrees with Guimarães et al. (2014), who analyzed the effect seasons on quail performance in the semiarid region of Paraíba and observed temperature values above the TCZ at the hottest hours of the day. According to Furtado et al. (2011), birds raised out of the ideal temperature may have a decrease in production performance and egg quality.

Relative air humidity $(\mathrm{RH})$ in the afternoon was lower than in the morning (Table 2 and Figure 1); 88.4 and $80.9 \%$ for hours of lower temperature ( 3 to $9 \mathrm{~h}$ ) and 81.3 and $88.4 \%$ from 18 to $24 \mathrm{~h}$. The maximum $\mathrm{RH}$ was recorded at $6 \mathrm{~h}$ $(85.6 \%)$ and minimum $\mathrm{RH}$ at $15 \mathrm{~h}(78 \%)$. Both are above the values recommended by Oliveira (2007), who observed higher production when quails are housed in environments with $\mathrm{RH}$ between 65 and 70\%, showing that the place where the birds were housed suffered great influence from the environment, since high RH is a characteristic of the microregion of 'Brejo Paraibano, where this variable can reach up to $100 \%$ in certain periods of the year. These results are consistent with those of Lima et al. (2011), in studies with different levels of sodium for Japanese quails in the growth stage, who cite $\mathrm{RH}$ value of $81.7 \%$ inside the facilities in the city of Fortaleza-CE, which, associated with high temperatures, promoted an environment considered as stressful to the animals.

Air temperature above the TCZ and high RH can lead to stress to the birds, since these climatic elements are highly correlated to animal thermal comfort and, at very high temperatures, the primary means of heat dissipation by birds is evaporation, which depends on relative air humidity (Baêta \& Souza, 2010).

The highest values of temperature-humidity index (THI) were recorded at the hottest hours of the day (Figure 2), from 9 to $15 \mathrm{~h}$ (73.4 and 73.7). THI showed increasing values until 12 $\mathrm{h}$ and decreasing values from this time on; at the most critical hours of the day (12 and $15 \mathrm{~h}$ ), there was no heat discomfort for the quails. The comfort indicator THI corroborates the results obtained by Oliveira et al. (2011), who studied laying hens raised in different production systems and observed comfort conditions within the established range, i.e., from 71 to 75 . The animal-environment interaction must be considered in the search for higher yields, and the different animal responses to the peculiarities of each region are determinant for a successful poultry farming system. Jácome et al. (2012), studying quail production performance, observed mean THI

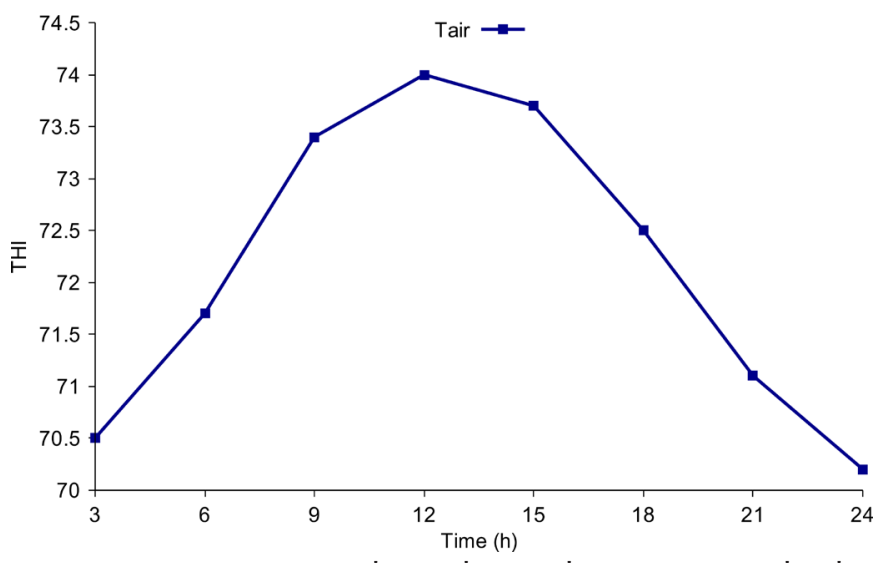

Figure 2. Temperature-humidity index (THI) inside the facility as a function of time

of 70.03, justifying a prevalence of the thermal comfort zone in the studied environment.

There was significant effect $(\mathrm{P}<0.05)$ between diet and time for the respiratory rate (RR) (Table 3 ) and the highest means occurred in the afternoon $\left(29.7 \mathrm{mov}^{\mathrm{min}}{ }^{1}\right)$, which were superior to those in the morning, regardless of the electrolyte balance of the diet. This occurred because this is the hottest period of the day, with higher air temperature (Figure 1), and the environmental factors influenced the physiological indices of the animals. RR is an important physiological parameter for the characterization of the comfort/stress condition of animals (Santos et al., 2006). The values obtained in the present study are within the RR range considered as ideal for birds, which must be from 20 to $30 \mathrm{mov} \mathrm{min}^{-1}$, with mean of $25 \mathrm{mov} \mathrm{min}^{-1}$ (Souza et al., 2005). However, the environment did not cause discomfort to the quails.

Laying quails raised within the TCZ can express their best productive characteristics (Nazareno et al., 2009), because maintaining RR within physiological levels is fundamental, especially to maintain blood $\mathrm{pH}$ normal and avoid problems such as blood alkalosis. The values in the present study were lower than those reported by Costa et al. (2012), who studied physiological indicators in the production of broiler chickens and observed minimum and maximum RR of 46.83 and $58.96 \mathrm{mov} \mathrm{min}^{-1}$, respectively. In comparison to laying hens and broiler chickens, quails have physiological characteristics very similar to those of chickens, which is the reason why they are usually subjected to the same management practices. However, abrupt alterations in RR show that the animal is in an uncomfortable environment, which was not observed in the present study.

As to cloacal temperature (CT), the means of the periods did not differ statistically $(\mathrm{p}<0.05)$, with small variation and mean of $41.0^{\circ} \mathrm{C}$ (Table 3 ). It should be pointed out that CT is one of the physiological parameters used to determine if the animal is or not in thermal balance with the environment (Santos et al., 2006), because it is a mechanism used by birds to release the stored heat. Nazareno et al. (2009) also cite $\mathrm{CT}$ values around 41 and $42{ }^{\circ} \mathrm{C}$ in broiler chickens raised in paddock and confined systems.

As to the body surface temperature (BST), the means were similar in both periods, ranging from 30.1 to $33.4{ }^{\circ} \mathrm{C}$ (Table 3 ) and both were observed when the quails were housed 
Table 3. Means of respiratory rate (RR), cloacal temperature (CT) and body surface temperature (BST) of Japanese quails in two periods

\begin{tabular}{|c|c|c|c|c|c|c|}
\hline \multirow{2}{*}{ Period } & \multicolumn{6}{|c|}{ Treatments" } \\
\hline & 1 & 2 & 3 & 4 & 5 & 6 \\
\hline & \multicolumn{6}{|c|}{ (RR) } \\
\hline Morning & $26.4 \mathrm{ABb}$ & $23.4 \mathrm{Bb}$ & $26.4 \mathrm{ABb}$ & $27.9 \mathrm{Ab}$ & $22.8 \mathrm{Bb}$ & $24.8 \mathrm{ABb}$ \\
\hline \multirow[t]{2}{*}{ Afternoon } & $29.7 \mathrm{Aa}$ & $27.9 \mathrm{Aa}$ & $29.1 \mathrm{Aa}$ & $27.6 \mathrm{Aa}$ & $28.2 \mathrm{Aa}$ & $28.2 \mathrm{Aa}$ \\
\hline & \multicolumn{6}{|c|}{ (CT) } \\
\hline Morning & $41.4 \mathrm{Aa}$ & $41.3 \mathrm{Aa}$ & $41.4 \mathrm{Aa}$ & $41.3 \mathrm{Aa}$ & $41.3 \mathrm{Aa}$ & $41.3 \mathrm{Aa}$ \\
\hline \multirow[t]{2}{*}{ Afternoon } & $41.2 \mathrm{Aa}$ & $41.4 \mathrm{Aa}$ & $41.8 \mathrm{Aa}$ & $41.8 \mathrm{Aa}$ & $41.5 \mathrm{Aa}$ & $41.6 \mathrm{Aa}$ \\
\hline & \multicolumn{6}{|c|}{ (BST) } \\
\hline Morning & $30.8 \mathrm{Aa}$ & $30.9 \mathrm{Aa}$ & $30.1 \mathrm{Aa}$ & $31.7 \mathrm{Aa}$ & $31.3 \mathrm{Aa}$ & $31.5 \mathrm{Aa}$ \\
\hline Afternoon & $33.0 \mathrm{Aa}$ & $32.7 \mathrm{Aa}$ & $33.4 \mathrm{Aa}$ & $31.8 \mathrm{Aa}$ & $32.7 \mathrm{Aa}$ & $32.3 \mathrm{Aa}$ \\
\hline
\end{tabular}

\# For details of treatments see Table 1

*Means followed by the same letter, uppercase in the column and lowercase in the row, do not differ by Tukey test at 0.05 probability level

consuming Diet 3. Gomes et al. (2010), studying semi-weighted laying hens after laying peak, cite that the electrolyte balance of the diet influenced the respiratory rate and mean BST of the animals, justifying that they were subjected to heat stress. Body surface temperature should be used to measure the state of stress or comfort of the animals; however, since this parameter is correlated with environmental variables, there is an approximation of the sensitivity of these animals under different conditions (Cangar et al., 2008).

Electrolyte balance influenced the values of respiratory rate of quails with significant difference in RR in the morning ( $p$ $<0.05$ ), but the values were similar in the afternoon, showing higher influence from the environment on this variable. The mean values of CT and BST were not influenced by the electrolyte balance of the diet.

There was a significant effect $(\mathrm{p}<0.05)$ on feed consumption, water consumption, production and weight and mass of eggs (Table 4), in relation to the levels of electrolyte balance of the diet. Quails housed in treatments 2 and 4 showed the highest feed consumptions (30.66 and $31.54 \mathrm{~g} \mathrm{~d}^{-1}$ ), respectively, differing from treatment $1\left(27.23 \mathrm{~g} \mathrm{~d}^{-1}\right)$, but not differing statistically from the others. As to the treatments 4,5 and 6 , all of them had the inclusion of the amino acid valine in the composition of the diet. For being an essential amino acid in feed formulation and also limiting in older birds, when it is low in the protein of the diet, its main function is promoting a satisfactory increase in consumption. The difference in feed consumption between these treatments and treatment 1 is possibly due to the changes of the effects of this amino acid with age, thus modifying feed consumption by the quails, which ultimately influenced feed consumption and, consequently, its decrease, since this treatment participated, although in lower proportion, in the consumption of the total period.
The mean daily consumption of feed per quail (Table 4) was $29.55 \mathrm{~g} \mathrm{~d}^{-1}$, showing that the diets responded satisfactorily to the treatments. This is consistent with the literature, which reports that daily consumption by quails must be between 25 and $35 \mathrm{~g} \mathrm{~d}^{-1}$. Sucupira et al. (2007) observed mean consumption of $22.45 \mathrm{~g} \mathrm{~d}^{-1}$, and this difference is justified by the difference in the diets used. One of the factors that can influence consumption is temperature, i.e., with the increase in air temperature, birds stop consuming feed and start using mechanisms to dissipate heat from the body to the environment.

The highest water consumption (Table 4) was observed in quails fed with treatment $4\left(70.63 \mathrm{~mL} \mathrm{bird}^{-1} \mathrm{~d}^{-1}\right)$; on the other hand, the lowest consumption was observed in quails fed with treatment $5\left(58.06 \mathrm{~mL} \mathrm{bird}^{-1} \mathrm{~d}^{-1}\right)$. The mean water consumption $\left(64.38 \mathrm{~mL} \mathrm{bird}^{-1} \mathrm{~d}^{-1}\right)$ can be considered as high, which does not agree with the results obtained by Lima et al. (2011) in studies with laying quails in the growth stage fed with sodium-based feed, who observed mean consumption of $28.55 \mathrm{~mL} \mathrm{bird}^{-1} \mathrm{~d}^{-1}$. Thus, the data obtained in the present study confirm that the animals suffered heat stress, but the productive performance was not affected. As observed by Gama (2011), the increase in feed consumption by birds is associated with the increment in water consumption. However, birds consume more water when air temperature increases. Thus, it is important that the animals have access to a sufficient amount of water with adequate quality and temperature, especially in the dry period, because the capacity to lose heat from the body has direct influence on weight gain, egg production and survival rate. In addition, water consumption can be doubled or triplicated during the periods of thermal stress.

Rodrigues et al. (2007), studying levels of sodium requirements in Japanese quails raised in the microregion of "Brejo Paraibano", reported that the use of deionized water

Table 4. Feed consumption (FC), water consumption (WC), egg production (EP), mean weight of eggs (MWE), mass of eggs (EM), feed conversion per mass of eggs (FCME) and per dozen of eggs (FCDE) of quails, according to the levels of electrolyte balance of the diet

\begin{tabular}{|c|c|c|c|c|c|c|c|}
\hline Treatment\# & $F C\left(g d^{-1}\right)$ & WC (mL) & EP (\%) & MWE (g) & $\overline{M E}(g)$ & $\overline{\text { FCME }\left(\mathrm{kg} \mathrm{g}^{-1}\right)}$ & FCDE $\left(\mathrm{kg} \mathrm{dz^{-1 } )}\right.$ \\
\hline 1 & $27.20 \mathrm{~b}$ & $63.13 a b$ & $75.8 \mathrm{~b}$ & $11.50 \mathrm{a}$ & $9.1 \mathrm{~b}$ & $2.29 \mathrm{a}$ & $0.34 \mathrm{a}$ \\
\hline 2 & $30.66 \mathrm{a}$ & $65.64 a b$ & $84.6 a b$ & $11.20 a b$ & $10.3 \mathrm{a}$ & $2.34 \mathrm{a}$ & $0.34 \mathrm{a}$ \\
\hline 3 & $29.68 \mathrm{ab}$ & $67.07 \mathrm{ab}$ & $78.7 \mathrm{ab}$ & $11.20 a b$ & $10.5 \mathrm{a}$ & $2.36 \mathrm{a}$ & $0.33 \mathrm{a}$ \\
\hline 4 & $31.54 \mathrm{a}$ & $70.63 \mathrm{a}$ & $82.3 a b$ & $11.64 \mathrm{a}$ & $9.7 \mathrm{a}$ & $2.61 \mathrm{a}$ & $0.36 \mathrm{a}$ \\
\hline 5 & $29.43 a b$ & $58.06 \mathrm{~b}$ & $79.8 \mathrm{ab}$ & $11.15 b$ & $9.1 \mathrm{~b}$ & $2.31 \mathrm{a}$ & $0.32 \mathrm{a}$ \\
\hline 6 & $29.37 a b$ & $58.16 b$ & $85.3 \mathrm{a}$ & $11.64 \mathrm{a}$ & $9.1 \mathrm{~b}$ & $2.47 \mathrm{a}$ & $0.33 \mathrm{a}$ \\
\hline Mean & 29.55 & 64.38 & 81.53 & 11.38 & 9.63 & 2.35 & 0.34 \\
\hline CV (\%) & 3.67 & 6.77 & 3.55 & 4.68 & 3.55 & 5.08 & 4.24 \\
\hline
\end{tabular}

\# For details of treatments see Table 1

* Means followed by the same letter, uppercase in the column and lowercase in the row, do not differ by Tukey test at 0.05 probability level 
promotes more reliable, plausible results, which certainly guarantee research results that promote improvements on quail performance. Raquel et al. (2010), in experiment with Italian quails in the state of Ceará, observed minimum and maximum temperatures of 28 and $32{ }^{\circ} \mathrm{C}$ and relative humidity of $86 \%$, besides an increase in feed conversion and water consumption.

There was significant difference in egg production only between treatment $1(75.8 \%)$ and treatment 6 (85.3\%), which had reduction in crude protein and higher level of electrolyte balance (Table 4), indicating that the animals directed most consumed nutrients to egg production. Santos et al. (2011), studying broiler breeders, obtained significant improvement in egg production after adding electrolytes in the feed. The mean egg production $(81.53 \%)$ is consistent with the mean for quail production in Brazil, similar to the values reported by Móri et al. (2005), 82.27\%, and Guimarães et al. (2014), who observed higher production values, with lower consumption of nutrients, in the comparison between Japanese and European strains, in two seasons of the year.

The mean weight of eggs was $11.38 \mathrm{~g}$, similar to that reported by Umigi et al. (2012), who studied Japanese quails fed with diets supplemented with different threonine levels and observed a value of $11.3 \mathrm{~g}$. Gravena et al. (2011), studying Japanese quails supplemented with organic minerals, observed that egg weight varied from 10.95 to $11.19 \mathrm{~g}$, under air temperature of $21.3^{\circ} \mathrm{C}$ and relative humidity of $76.4 \%$

The overall mean of mass of eggs was $9.63 \mathrm{~g} \mathrm{bird}^{-1} \mathrm{~d}^{-1}$, which is similar to the value obtained by Costa et al. (2008), who studied meat quails and observed mean mass of $9.82 \mathrm{~g} \mathrm{bird}^{-1} \mathrm{~d}^{-1}$. Feed conversion per mass and per dozen of eggs was not affected by the different levels of electrolyte balance, remaining within the range considered as normal for laying quails and similar to the values cited by Costa et al. (2011).

\section{Conclusions}

1. Climatic variations between 9 and $15 \mathrm{~h}$ were above the thermal comfort zone for laying quails, thus causing heat stress.

2. Quail productive performance was not affected, since physiological variables remained within the comfort zone and homeothermy was maintained.

\section{Literature Cited}

Baêta, F. C.; Souza, C. F. Ambiência em edificações rurais - Conforto animal. 2.ed. Viçosa: UFV, 2010. 269p.

Bunffington, D. E.; Collazo-Arocho, A.; Canton, G. H. D.; Thatcher, W. W.; Collier, R. J. Black globe-humiddity confot index for dairy cows. St. Joseph: American Society of Agricultural Engineers, 1997. 19p. Paper 77-4517

Cangar, O.; Aerts, J. M.; Buyse, J.; Berckmans, D. Quantification of the spatial distribution of surface temperatures of broilers. Poultry Science, v.87, p.2493-2499, 2008. http://dx.doi.org/10.3382/ ps.2007-00326

Costa, C. H. R.; Barreto, S. L. T.; Filho, R. M. M.; Araujo, M. S.; Umigi, R. T.; Lima, H. J. A. Avaliação do desempenho e da qualidade dos ovos de codornas de corte de dois grupos genéticos. Revista Brasileira de Zootecnia, v.37, p.1823-1828, 2008. http://dx.doi. org/10.1590/S1516-35982008001000016
Costa, E. M. da S.; Dourado, L. R. B.; Merval, R. R. Medidas para avaliar o conforto térmico em aves. Publicações em Medicina Veterinária e Zootecnia, v.6, p.1-20, 2012.

Furtado, D. A.; Mota, J. K. M.; Nascimento, J. W. B. do; Silva, V. R. da; Tota, L. C. A. Produção de ovos de matrizes pesadas criadas sob estresse térmico. Revista Brasileira de Engenharia Agrícola e Ambiental, v.15, p.748-753, 2011. http://dx.doi.org/10.1590/ S1415-43662011000700014

Gama, N. M. S. Q. Qualidade química e bacteriológica da água utilizada na dessedentação de aves. $14^{\circ}$ Curso de sanidade Avícola Fort Dodge. http://www.fortdodge.com.br/14sanidade/ pdf/16importanciadaaguanaavicultura.pdf.23 Mar.2011.

Gomes, D. L. S.; Saraiva, E. P.; Magalhães, T. S.; Fonseca, V.; Silva, A. L.; Oliveira, C. F. S. Efeito do balanço eletrolítico em dietas com redução protéica sobre parâmetros fisiológicos de poedeiras semi pesadas após pico de postura. In: Reunião Anual da Sociedade Brasileira de Zootecnia, 47, 2010, Salvador. Anais... Salvador: Universidade Federal da Bahia, 2010. CD-Rom

Gravena, R. A.; Marques, R. H.; Picarelli, J.; Silva, J. D. T.; Roccon, J.; Hada, F. H.; Queiroz, S. A.; Moraes, V. M. B. Suplementação da dieta de codornas com minerais nas formas orgânicas sobre o desempenho e qualidade dos ovos. Arquivo Brasileiro de Medicina Veterinária e Zootecnia, v.63, p.1453-1460, 2011. http://dx.doi. org/10.1590/S0102-09352011000600024

Guimarães, M. C. C.; Furtado, D. A.; Nascimento, J. W. B. do; Tota, L. C. A.; Silva, C. M.; Lopes, K. B. P. Efeito da estação do ano sobre o desempenho produtivo de codornas no semiárido paraibano. Revista Brasileira de Engenharia Agrícola e Ambiental, v.18, p.231237, 2014. http://dx.doi.org/10.1590/S1415-43662014000200015

Jácome, I. M. D. T.; Borille, R.; Rossi, L. A.; Rizzotto, D. W.; Becker, J. A.; Sampaio, C. de F. R. Desempenho produtivo de codornas alojadas em diferentes sistemas de iluminação artificial. Arquivos de Zootecnia, v.61, p.449-456. 2012. http://dx.doi.org/10.4321/ S0004-05922012000300013

Lima, R. C.; Freitas, E. R.; Raquel, D. L.; Sá, N. L.; Lima, C. A. de; Paiva, A. C. Níveis de sódio para codornas japonesas na fase de crescimento. Revista Brasileira de Zootecnia, v.40, p.352-360, 2011. http://dx.doi.org/10.1590/S1516-35982011000200017

Minafra, C. S.; Moraes, G. H. K.; Lopes, A. C. C.; Lopes Júnior, C. O.; Vieites, F. M.; Rezende, C. S. M.; Viu, M. A. O. Balanço eletrolítico e proteico dietéticos sobre as aminotransferases hepáticas, renais e séricas e teores séricos de magnésio e cloro de frangos de corte. Ciência Animal Brasileira, v.10, p.425-437, 2009.

Móri, C.; Garcia, E. A.; Pavan, A. C.; Piccinin, A.; Scherer, M. R.; Pizzolante, C. C. Desempenho e qualidade dos ovos de codornas de quatro grupos genéticos. Revista Brasileira de Zootecnia, v.34, p.864-869, 2005. http://dx.doi.org/10.1590/S151635982005000300018

Moura, A. M. A.; Fonseca, J. B.; Rabelo, C. B. V.; Takata F. N.; Oliveira, N. E. T. Desempenho e qualidade do ovo de codornas japonesas alimentadas com rações contendo sorgo. Revista Brasileira de Zootecnia, v.39, p.2697-2702, 2010. http://dx.doi.org/10.1590/ S1516-35982010001200021

Nazareno, A. C.; Pandorfi, H.; Almeida, G. L. P.; Giongo, P. R.; Pedrosa, E. M. R.; Guiselini, C. Avaliação do conforto térmico e desempenho de frangos de corte sob regime de criação diferenciado. Revista Brasileira de Engenharia Agrícola Ambiental, v.13, p.802-808, 2009. http://dx.doi.org/10.1590/S1415-43662009000600020 
NRC - National Research Council - Nutrient requirements of poultry. 9.ed. Washington: National Academy of Sciences, 2004, 155p.

Oliveira, B. L. Manejo em granjas automatizadas de codornas de postura comercial. In: Simpósio Internacional de Coturnicultura, 3, 2007. Lavras. Anais... Lavras: Núcleo de Estudos em Ciência e Tecnologia Avícolas, 2007, p.11-16.

Oliveira, C. F. S.; Costa, F. G. P.; Silva, J. H. V.; Goulart, C. C.; Saraiva, E. P.; Givisiez, P. E. N.; Lobato, G. B. V.; Bezerra, R.M. Electrolyte balance in diets with reduced protein for semi-weighted laying hens in the second production cycle. Revista Brasileira de Zootecnia, v.41, p.1671-1675, 2012. http://dx.doi.org/10.1590/ S1516-35982012000700016

Oliveira, E. L.; Gomes, F. A.; Silva, C. C.; Delgado, R. C.; Ferreira, J. B. Desempenho, Características Fisiológicas e Qualidade de Ovos de Poedeiras Isa Brown Criadas em Diferentes Sistemas de Produção no Vale do Juruá - Acre. Enciclopédia Biosfera, Centro Científico Conhecer - Goiânia, v,7, p.339-347, 2011.

Raquel, D. L.; Lima, R. C.; Freitas, E. R.; Sá, N. L.; Xavier, R. P. S.; Paiva, A. C. Níveis de cloro para codornas italianas destinadas à produção de carne. Acta Scientiarum. Animal Sciences v.32, p.39-45, 2010.

Richards, S. A. The significance of changes in the temperature of the skin and body core of the chicken in the regulation of heat loss. The Journal of Physiology, v.216, p.1-10, 1971. http://dx.doi. org/10.1113/jphysiol.1971.sp009505

Rodrigues, V. P.; Costa, F. G. P; Silva, J. H. V.; Goulart, C. C.; Lima, M. R.; Figueiredo, D. F.; Lima Neto, R. C. Exigências de sódio para codornas japonesas em crescimento de 24 a 40 dias de idade. In: Congresso Brasileiro de Coturnicultura, 2, 2007. Anais... Lavras: Universidade Federal de Lavras, 2007. CD-Rom
SAEG - Sistema para Análises Estatísticas e Genéticas - versão 9.0. Viçosa: UFV, 2005.

Santos, J. R. S.; Souza, B. B.; Souza, W. H.; Cezar, M. F.; Tavares, G. P. Respostas fisiológicas e gradientes térmicos de ovinos das raças Santa Inês, Morada Nova e de seus cruzamentos com a raça Dorper às condições do semi-árido nordestino. Ciências e Agrotecnologia, v.30, p.995-1001, 2006. http://dx.doi.org/10.1590/ S1413-70542006000500025

Santos, T. T.; Santos, S. A.; Borges, S. A.; Silva, A. V. F.; Maiorka, A. Aplicação estratégica do balanço eletrolítico em dietas para matrizes pesadas. Ciência Rural, v.41, p.895-900, 2011. http:// dx.doi.org/10.1590/S0103-84782011000500026

Silva, J. H. V.; Jordão Filho, J.; Costa, F. G. P.; Lacerda, P. B.; Vargas, D. G. V.; Lima, M. R. Exigências nutricionais de codornas. Revista Brasileira de Saúde e Produção Animal, v.13, p.775-790, 2012. http://dx.doi.org/10.1590/S1519-99402012000300016

Souza, L. M. G.; Murakami, A. E.; Sakamoto, M. I.; Fernandes, J. I. M. Digestibilidade e Desempenho de Codorna Japonesa (Coturnix coturnix japônica) alimentadas com semente de linhaça. In: Reunião Anual da Sociedade Brasileira de Zootecnia, 42, 2005, Goiânia. Anais... Goiânia: Sociedade Brasileira de Zootecnia, 2005. CD- Rom Sucupira, F. S.; Fuentes, M. F. F.; Freits, E. R.; Braz, N. de M. Alimentação de codornas de postura com rações contendo levedura de cana-de-açúcar. Ciência Rural, v.37, p.528-532, 2007. http://dx.doi.org/10.1590/S0103-84782007000200036

Umigi, R. T.; Barreto, S. L. T.; Reis, R. S.; Mesquita Filho, R. M. Araújo, M. S. Níveis de treonina digestível para codornas japonesas na fase de produção. Arquivo Brasileiro de Medicina Veterinária e Zootecnia, v.64, p.658-664, 2012. http://dx.doi.org/10.1590/ S0102-09352012000300018 